\title{
LACK OF CAVE-ASSOCIATED MAMMALS INFLUENCES THE FUNGAL ASSEMBLAGES OF INSULAR SOLUTION CAVES IN EASTERN CANADA
}

\author{
Karen J. Vanderwolf ${ }^{1,2}$, David Malloch $^{1}$, Natalia V. Ivanova ${ }^{3}$, and Donald F. McAlpine ${ }^{1}$
}

\begin{abstract}
The biogeography of cave fungi and factors that influence community composition are poorly known. The movement of animals into caves from the outside environment is thought to be one factor that affects cave mycota. Islands often have different faunal assemblages from the mainland, and this may affect the fungal diversity of island caves. In 2014 we swabbed walls in three natural solution caves on Anticosti Island, Quebec, to determine the composition of cave fungal assemblages present relative to well-studied nearby mainland sites. At least one of these caves, Grotte à la Patate in Anticosti National Park, appears to support overwintering bats. Culture-dependent methods were used to establish pure cultures, and fungi were identified by a combination of morphology and genetic sequencing. A total of 54 fungal taxa were identified, with a mean of $7.4 \pm 3.9$ taxa per swab. The most common taxa isolated were Penicillium spp., Pseudogymnoascus pannorum sensu lato, P. roseus, Trichoderma sp., Cladosporium spp., Thysanophora spp., Mucor sp., and Trichosporon dulcitum. Pseudogymnoascus destructans $(P d)$, the causative agent of the fungal disease white-nose syndrome in bats, was not detected, and we conclude that $P d$ was not present in the three sampled caves as of summer 2014. Two of the caves did not appear to be suitable bat hibernacula based on microclimate, although diverse fungal assemblages were detected on the walls. Several other fungal taxa common to bat hibernacula on the mainland, in addition to $P d$, were lacking from Anticosti Island caves. We suggest that fungal assemblages on Anticosti Island are influenced by the absence of non-volant cave-visiting mammals on the island, particularly porcupines (Erethizon dorsatum) and raccoons (Procyon lotor), both frequent cave associates elsewhere in Maritime Canada.
\end{abstract}

\section{INTRODUCTION}

Little is known about the biogeography of fungi in caves and those factors that influence the composition of the mycological community in such habitats. Fungi present in caves are generally introduced from the non-subterranean environment by water, air, and fauna; it has yet to be determined if endemic cave fungal species exist (Vanderwolf et al., 2013a). Insects, mammals, and their associated dung are thought to influence the diversity of cave mycota by introducing spores from the surface environment and by providing a substrate for fungal growth within caves (Min, 1988; Dickson, 1975). There is evidence that some fungal species, when present in caves, are associated with specific fauna. For instance, several fungal species are known to be associated with insects in caves, such as entomopathogenic fungi (Yoder et al., 2009).

Anticosti Island, located in the Gulf of St. Lawrence, Quebec, Canada, 35 to $74 \mathrm{~km}$ from the mainland, is populated by only five non-volant native mammals, although at least twelve other mammal species have been introduced, either successfully or unsuccessfully, since European settlement of the region (Cameron, 1958). Acoustic surveys conducted in Anticosti National Park in August-September 2007 have confirmed the presence of native bats, including Myotis spp. (M. lucifugus or M. septentrionalis), Lasiurus cinereus, and $L$. borealis (Plamondon 2009). Several caves on Anticosti Island have been reported as potential bat hibernacula, but winter access is difficult, and bats have been observed overwintering in only a single cave on the island, Grotte à la Patate (Julien Mainguy, Ministère des Ressources naturelles et de la Faune, per. comm. to DFM April 2010). Nonetheless, an extensive karst topography suggests that other bat hibernacula may exist on the island. Non-volant mammals that are known to frequently enter caves on the adjacent mainland, including Erethizon dorsatum (porcupine), mustelids, and Procyon lotor (raccoon), are absent on Anticosti Island (Newsom, 1937; Cameron, 1958; Gaetan Laprise, Québec Ministère des Forêts, de la Faune et des Parcs per comm. to KJV and DFM). However, deer mice (Peromyscus maniculatus), known to enter mainland caves in the region, are present (Newsom, 1937; Cameron, 1958; Trevor-Deutsch, 1973; Darmon et al., 2013). The arthropod diversity in caves on Anticosti Island is unknown.

\footnotetext{
* Corresponding author: kjvanderw@gmail.com

${ }^{1}$ New Brunswick Museum, 277 Douglas Avenue, Saint John, NB, Canada E2K 1E7

${ }^{2}$ Canadian Wildlife Federation, 350 Promenade Michael Cowpland Drive, Kanata, ON Canada K2M 2W1

${ }^{3}$ Canadian Centre for DNA Barcoding, Centre for Biodiversity Genomics, Biodiversity Institute of Ontario, University of Guelph, 50 Stone Road East, Guelph, N1G 2W1
} 


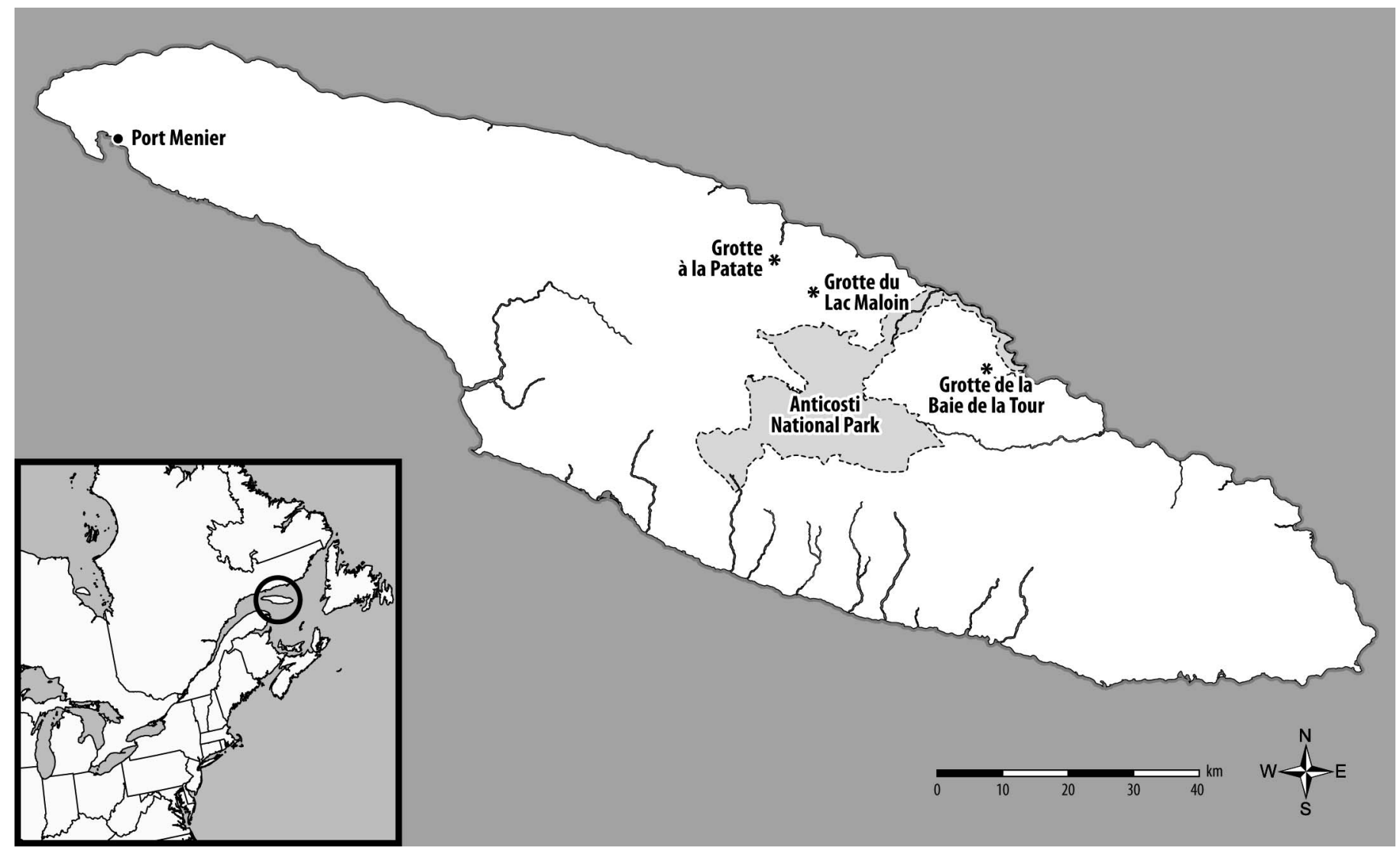

Figure 1. Anticosti Island, Quebec, with the location of the three study caves marked with asterisks. Port Menier is the only permanent settlement on the island.

The fungal assemblage in caves on the mainland in nearby New Brunswick has been relatively intensively studied (Vanderwolf et al., 2013b, 2016a). Our objectives were to document the mycota in caves on Anticosti Island and compare these to previous studies in caves in New Brunswick and to assess factors that may influence the fungal assemblage in the caves, such as microclimate and the presence of mammals, running water, and arthropods.

\section{Methods}

\section{Site Description}

Anticosti Island is $7943 \mathrm{~km}^{2}$ in area, with a bedrock of Silurian and Ordovician limestone. The island is separated from the mainlands of Quebec and New Brunswick by marine straits 35 to $74 \mathrm{~km}$ wide. Although the human population of Anticosti Island can double in the summer (Danièle Morin, Quebec Ministry of Natural Resources, per. comm. to KJV and DFM), the only permanent settlement is Port-Menier, on the western end of the island, which supports a year-round population of about 250 people. The mean temperature on the island 2010-2014 was $3.48^{\circ} \mathrm{C} \pm 1.1 \mathrm{SD}$, with a minimum average of $-10.3 \pm 4.0^{\circ} \mathrm{C}$ in February to a maximum of $16.9 \pm$ $0.9^{\circ} \mathrm{C}$ in July (Environment Canada, 2015).
We visited three natural limestone caves on Anticosti Island in July 2014 (Fig. 1). We followed the protocol of the United States Fish and Wildlife Service (2012) for minimizing the spread of Pseudogymnoascus destructans, the agent of the fungal disease white-nose syndrome in bats, during all visits to caves on Anticosti Island. Point measurements of cave temperature and relative humidity were taken in each cave using a Kestral 3000 Pocket Weather Meter (part\# 0830FOR; Nielsen-Kellerman, Boothwyn, PA). Each cave was surveyed for the presence of bat carcasses, guano, and signs of invertebrates and other vertebrates.

Grotte à la Patate, located in Anticosti National Park $\left(\mathrm{N} 49.6545^{\circ}, \mathrm{W} 62.9503^{\circ}\right)$, was visited July 7, 2014. This cave is the third largest in Quebec, with at least $625 \mathrm{~m}$ of passage and the largest underground room (Fig. 2) in the province (map in Roberge et al., 1985; Lauriol et al., 1987). The cave walls are muddy and composed of fine-grained siltstone and Ordovician limestone. An active stream, with multiple small waterfalls along its length, flows through the main passage and out the large entrance. Approximately 50 to 70 roosting bats (likely Myotis lucifugus and M. septentrionalis) were reported in the cave October 1988, specifically in an offshoot from the main passage with no running or standing water (Danièle Morin, Québec Ministère des Forêts, de la Faune et des Parcs, per. comm. to KJV and DFM). The offshoot starts approx-

Journal of Cave and Karst Studies, December 2016 199 


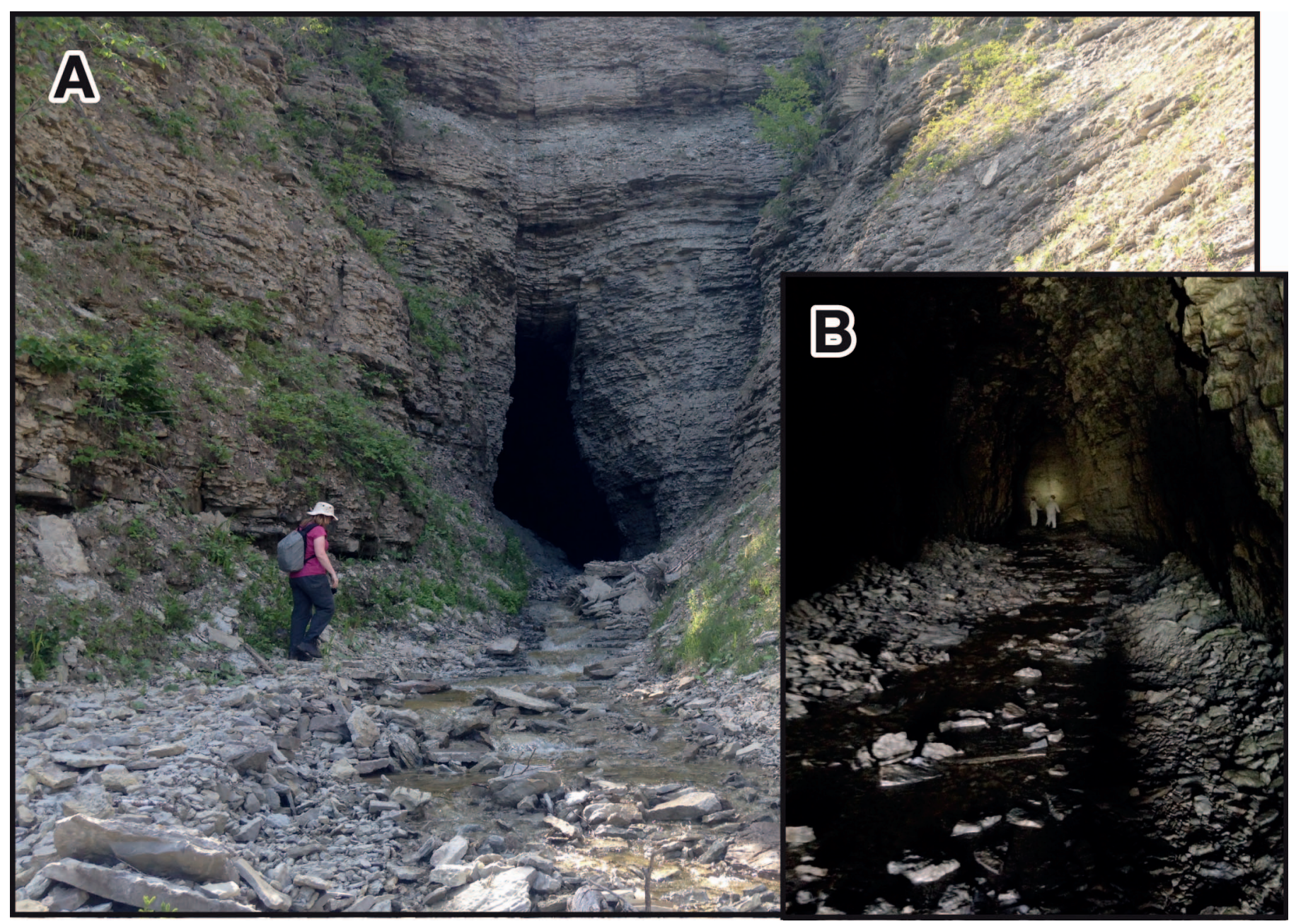

Figure 2. (A) entrance and (B) passage in Grotte à la Patate. Note that the entrance and large main passage are readily accessible to terrestrial mammals.

imately $55 \mathrm{~m}$ from the entrance. Regular public tours of this cave are conducted by national park staff during the summer months, and the location is well publicized in the tourist literature. Approximately one thousand tourists visit the park during the summer, several hundred of whom visit the cave annually (Anticosti National Park staff, per. comm. to DFM and KJV).

Grotte de la Baie de la Tour (N49.5043, W62.4980) was visited July 9, 2014. The cave has approximately $270 \mathrm{~m}$ (Danièle Morin, Québec Ministère des Forêts, de la Faune et des Parcs, per. comm. to KJV and DFM) of narrow, high passage with an active stream and multiple small waterfalls along its length. Debris and foam (Fig. 3) high on the walls suggests the cave passage fills with water in spring and after heavy rains. The cave is well marked and close to a road, with a small viewing platform overlooking the entrance. Waterfalls spanning the entrance to the cave likely discourage most visitors.

Grotte du lac Maloin (N49.61042 ${ }^{\circ}$, W62.87001 ${ }^{\circ}$ ) was visited July 11, 2014. This cave has about $50 \mathrm{~m}$ of mostly low, narrow passage with an active stream featuring multiple small waterfalls and several flowstone features (Fig. 4). The integrity of the entrance and speleothems indicates the cave is seldom visited. Detritus observed on the cave ceiling suggests the entire passage floods on occasion.

\section{Fungal SAMPLING}

Walls in the dark zone of the caves were swabbed with a sterile, dry cotton-tipped applicator. In Grotte à la Patate swabs were taken at the back of the offshoot some $70 \mathrm{~m}$ from the entrance (Roberge et al., 1985), an area where roosting bats had been reported and where we observed bat guano on the walls and floor. In Grotte de la Baie de la Tour and Grotte du lac Maloin swabs were collected as far into the cave as was accessible; estimated at 50 to $100 \mathrm{~m}$ and about $30 \mathrm{~m}$, respectively, from the entrances. Each applicator was rubbed multiple times over a different 10 by $10 \mathrm{~cm}$ area of the wall, with a new applicator used for each swab. After swabbing, the applicator was immediately streaked across the agar surface in a petri plate. Diluting streaks were completed in the cave 


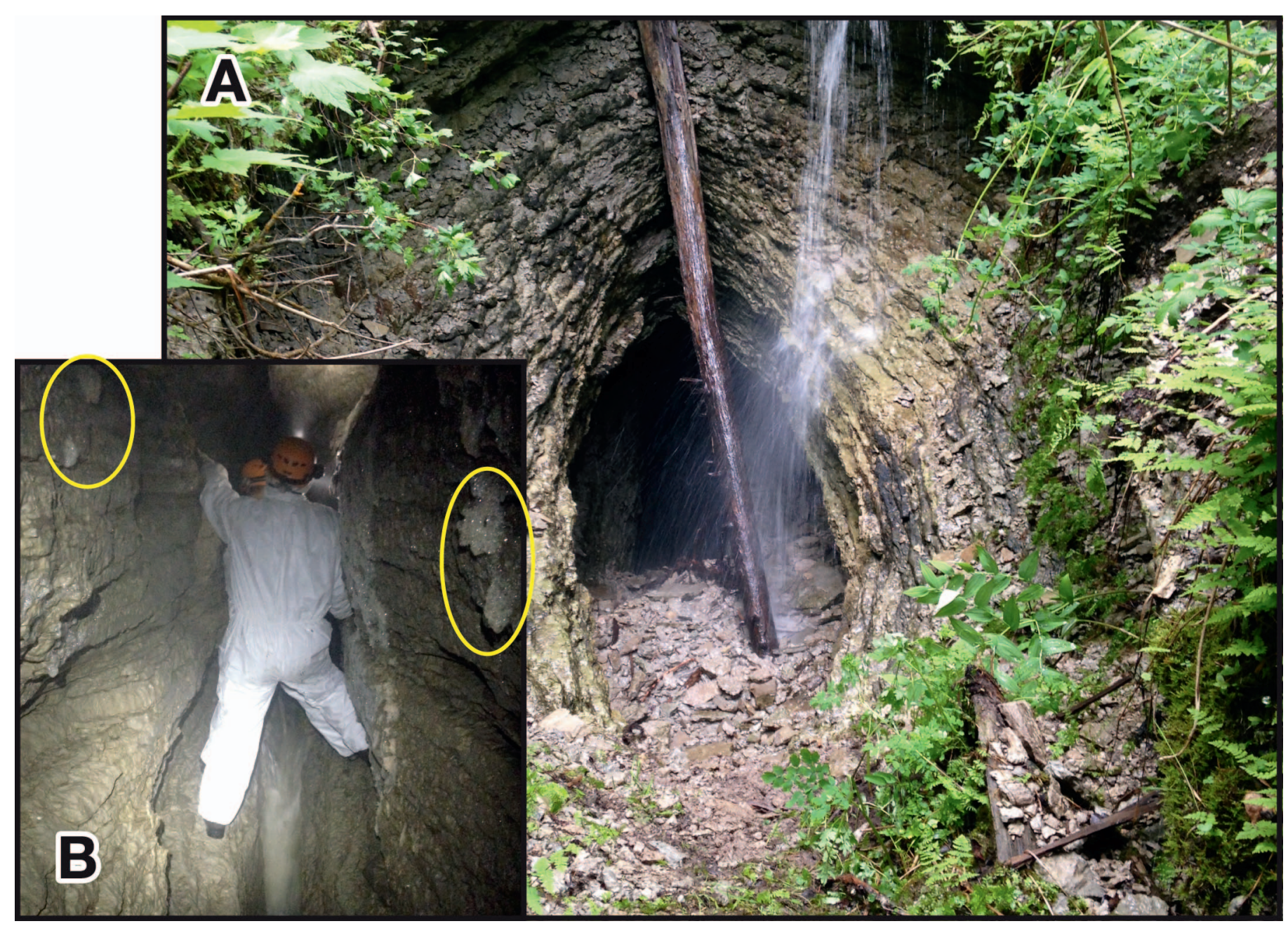

Figure 3. Entrance (A) to and passage (B) in Grotte de la Baie de la Tour. Note foam from recent high water high on the cave wall near the ceiling, circled. Foam selectively traps the conidia of a wide variety of fungal species, while severe intermittent flooding in this cave probably precludes use by hibernating bats.

within $1 \mathrm{~h}$ of the initial streak, after which plates were sealed in situ with Parafilm (Pechiney Plastic Packaging, Chicago, IL). Dextrose-peptone-yeast extract agar (DPYA) was used (Papavizas and Davey, 1959), infused with the antibiotics chlortetracycline $(30 \mathrm{mg} / \mathrm{L})$ and streptomycin $(30 \mathrm{mg} / \mathrm{L})$. We have previously documented this as a superior medium for isolating $P$. destructans from the environment (Vanderwolf et al., 2016b).

In the laboratory, samples were incubated, inverted, in the dark at $7{ }^{\circ} \mathrm{C}$ in a low-temperature incubator (Model 2015, VWR International, Mississauga, ON, Canada), to approximate the subterranean environment. Samples were monitored over four months until no new cultures had appeared for three weeks on a plate or the plate had become overgrown with hyphae. Once fungi began growing on the plates, each distinct colony was subcultured to a new plate. DPYA without oxgall and sodium propionate was used for maintaining pure cultures.

\section{DNA EXTRACTION}

Fungal plugs were collected using sterile techniques from the pure fungal cultures. Total genomic DNA was extracted using plant-DNA extraction protocol (Ivanova et al., 2008) with minor modifications. In brief, ethanol-fixed tissue was transferred in a tube rack and dried at $56{ }^{\circ} \mathrm{C}$. Dried tissue was homogenized with a TissueLyser (Qiagen $\mathrm{GmbH}$, Hilden, Germany) using $3 \mathrm{~mm}$ tungsten carbide beads (Qiagen) and sterile sand at $30 \mathrm{~Hz}$ for $1 \mathrm{~min}$. A volume of $100 \mu \mathrm{L}$ of ILB buffer with Proteinase K (700 mM GuSCN, $30 \mathrm{mM}$ EDTA pH 8.0, $30 \mathrm{mM}$ Tris- $\mathrm{HCl} \mathrm{pH} 8.0,0.5 \%$ Triton $\mathrm{X}-100,5 \%$ Tween20 , and $2 \mathrm{mg} / \mathrm{mL}$ Proteinase $\mathrm{K}$ ) and was added to each sample. Samples were incubated at $56{ }^{\circ} \mathrm{C}$ for 1 hour, and $200 \mu \mathrm{L}$ of PBB1 buffer (Ivanova et al., 2008) was added to each sample followed by an incubation at $65{ }^{\circ} \mathrm{C}$ for $30 \mathrm{~min}$. A volume of $150 \mu \mathrm{L}$ of each lysate was transferred into a well in a $1 \mathrm{~mL}$ Acroprep 96-well plate with $1 \mu \mathrm{m}$ glass fiber media (Pall Life Sciences, Ann Arbor, MI, USA). The wash stages followed 


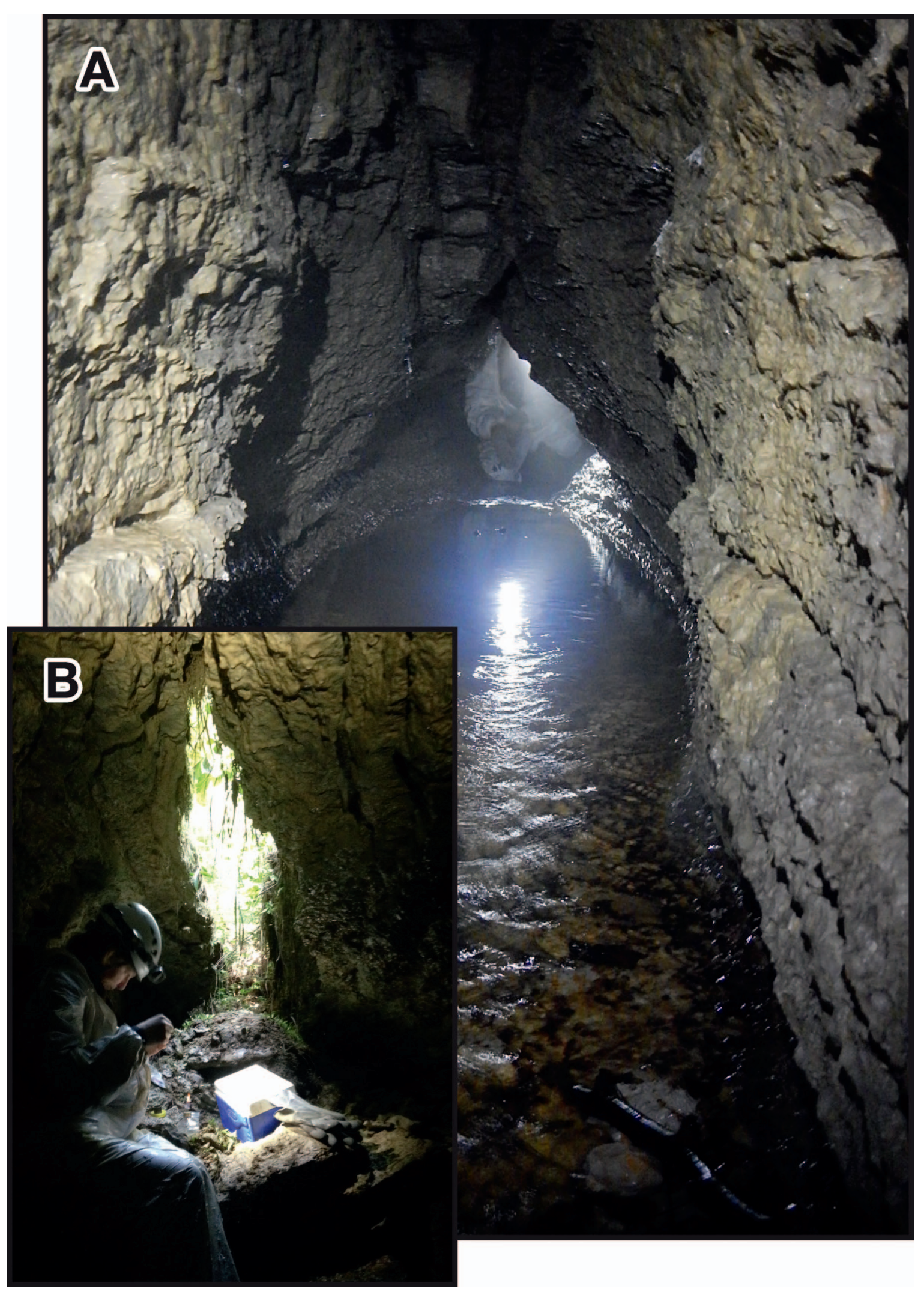

Figure 4. (A) Passage in and (B) entrance to Grotte du lac Maloin. Most passage is low with active development by a stream. 
K.J. Vanderwolf, D. Malloch, N.V. Ivanova, and D.F. McAlpine

Table 1. Temperature and relative humidity in three natural solution caves on Anticosti Island, Quebec in July 2014. The approximate distance from the cave entrance that dark zone readings were taken is also reported. $\mathrm{ND}=$ no data.

\begin{tabular}{|c|c|c|c|c|c|c|c|}
\hline \multirow[b]{2}{*}{ Cave } & \multicolumn{3}{|c|}{ Dark Zone } & \multicolumn{2}{|c|}{ Twilight Zone } & \multicolumn{2}{|c|}{ Outside } \\
\hline & Temp, ${ }^{\circ} \mathrm{C}$ & RH, \% & Distance, $\mathrm{m}$ & Temp, ${ }^{\circ} \mathrm{C}$ & $\mathrm{RH}, \%$ & Temp, ${ }^{\circ} \mathrm{C}$ & RH, \% \\
\hline \multirow{3}{*}{ Grotte à la Patate } & 8.8 & 83.3 & End of offshoot, 70 & ND & ND & ND & ND \\
\hline & 8.1 & 99.4 & Main passage, 50 & ND & ND & ND & ND \\
\hline & 12.1 & 99.4 & Main passage, 70 & ND & ND & ND & ND \\
\hline Grotte de la Baie de la Tour & 15.1 & 88.1 & $50-100$ & 13.6 & 85.4 & 17.8 & 100 \\
\hline Grotte du lac Maloin & 14.9 & 81.3 & 30 & 17.0 & 100 & 25.8 & 41.2 \\
\hline
\end{tabular}

standard protocol. DNA was eluted in $50 \mu \mathrm{L}$ of $10 \mathrm{mM}$ Tris$\mathrm{HCl} \mathrm{pH} 8.0$.

\section{PCR Amplification and SeQuencing}

Fungal primers ITS-1F (Gardes \& Bruns, 1993) and ITS 4 (White et al., 1990) were used for amplification of ITS1, 5.8S, and ITS2 regions. All PCR reactions had a total volume of $12.5 \mu \mathrm{L}$ and included: $6.25 \mu \mathrm{L}$ of $10 \%$ trehalose, $2.00 \mu \mathrm{L}$ of ultrapure water, $1.25 \mu \mathrm{L} 10 \times$ PCR Platinum Taq buffer [500 $\mathrm{mM} \mathrm{KCl}, 200 \mathrm{mM}$ Tris- $\mathrm{HCl}$ (pH 8.4)], $0.625 \mu \mathrm{L} \mathrm{MgCl} 2$ (50 $\mathrm{mM}$ ) (Invitrogen, Life Technologies), $0.125 \mu \mathrm{L}$ of each primer $(0.01 \mathrm{mM}), 0.0625 \mu \mathrm{L}$ of each dNTP $(10 \mathrm{mM}), 0.3 \mathrm{U}$ of Platinum DNA Polymerase $(5 \mathrm{U} / \mu \mathrm{L})$ (Invitrogen, Thermo Fisher Scientific), and $2.0 \mu \mathrm{L}$ of DNA template. The thermocycle profile for ITS region consisted of $94{ }^{\circ} \mathrm{C}$ for 2 min, 40 cycles of $94{ }^{\circ} \mathrm{C}$ for $30 \mathrm{~s}, 50^{\circ} \mathrm{C}$ for $30 \mathrm{~s}$, and $72{ }^{\circ} \mathrm{C}$ for 1 min, with a final extension at $72{ }^{\circ} \mathrm{C}$ for $5 \mathrm{~min}$. PCR products were visualized on a $2 \%$ agarose gel using an E-Gel96 Precast Agarose Electrophoresis System (Invitrogen). Bidirectional sequencing was done using the BigDye Terminator v.3.1 Cycle Sequencing Kit (Applied Biosystems, Thermo Fisher Scientific) on an ABI 3730xl Genetic Analyzer (Applied Biosystems, Life Technologies) as described in Hajibabaei et al. (2005). Bidirectional sequences were assembled in CodonCode 4.2.2 (CodonCode Corporation) and manually edited.

\section{Data Analysis}

Identifications were carried out by comparing the microand macromorphological characteristics of the microfungi to those traits appearing in the taxonomic literature and compendia (Domsch et al., 2007; Seifert et al., 2011) and using molecular techniques described above. Desiccant-dried cultures are preserved in the New Brunswick Museum (NBM\# F-05200-05245, 05283-05290). All collection data and specimen images for fungi identified by molecular techniques were uploaded to BOLD project Barcoding Bat-Associated Cave Fungi. Sequences were compared against the reference sequence records available in Barcode of Life Data Systems and the National Center for Biotechnology Information's megablast, excluding uncultured/environmental sample sequences. Nucleotide BLAST search results were visualized using MEGAN (v. 5.10.3). Additionally, the Mothur algorithm was utilized to assign posterior probability of sequence match to a local database of ITS sequences downloaded from Genbank (NCBI). Cumulative results were visualized using Tableau 7.0.

\section{RESUlts}

\section{ENVIRONMENTAL}

Grotte à la Patate had the coolest dark-zone temperatures compared to the other two caves (Table 1). Dark zone temperatures in Grotte à la Patate are similar to those recorded in bat hibernacula on the nearby mainland (Vanderwolf et al., 2012). Although bat guano was present, signs of dead bats or bat bones were not observed in Grotte à la Patate. No signs of occupancy by bats were observed in the other two caves. Signs of other mammals were not observed in the caves. The high summer temperatures recorded in the dark zones of Grotte de la Baie de la Tour and Grotte du lac Maloin in July, combined with short passage lengths, suggest that winter dark-zone temperatures are unstable and that the microclimate in these caves is unsuitable for hibernating bats.

Few arthropods were observed in Grotte à la Patate, and invertebrates were not detected in Grotte de la Baie de la Tour. Various dipterans were observed throughout Grotte du lac Maloin, and the cave-associated spider Meta ovalis was present at the entrance.

\section{FUNGI}

Fungi were isolated from all 22 swabs taken in the three caves, producing 183 isolates with a mean of $7.4 \pm 3.9$ fungal taxa per swab (Table 2). Pseudogymnoascus destructans was not detected. The most common of the 54 fungal taxa isolated were Penicillium spp. (isolated from $81.8 \%$ of swabs), Pseudogymnoascus pannorum sensu lato (54.5\%), P. roseus (50.0\%), Trichoderma sp. (40.9\%), Cladosporium spp. (36.4\%), Thysanophora spp. (36.4\%), Mucor sp. (31.8\%), and Trichosporon dulcitum (31.8\%). Grotte à la Patate appeared to have the lowest fungal diversity amongst the caves, despite more intensive sampling (Table 2). 
Table 2. Fungal taxa cultured from wall swabs in three natural solution caves on Anticosti Island, Quebec. The number of positive swabs for each fungal taxon in each cave is shown. $D=$ identified by DNA, M $=$ identified by morphology.

Cave

Fungi

\section{Grotte}

de la Baie Grotte du lac Grotte à la de la Tour

Maloin Patate

Ascomycota

Capnodiales

Cladosporium $\mathrm{sp}$.

C. cladosporioides (Fresen.) G.A. de Vries

Chaetothyriales

Phialophora sp.

Dothideales

Scleroconidioma sphagnicola Tsuneda, Currah \& Thormann

Eurotiales

Penicillium sp.

P. cf. janthinellum Biourge

P. cf. thomii Maire

Penicillium subgenus biverticillium

Thysanophora sp.

Thysanophora sp. 1

Thysanophora sp. 2

Helotiales

Identified to order only

Cadophora sp.

Catenulifera sp.

Chalara longipes (Preuss) Cooke

Cistella acuum (Alb. \& Schwein.) Svrcek

Hypocreales

Acremonium sp.

Beauveria sp.

Cosmospora obscura Rossman \& Samuels

C. viridescens (C. Booth) Grafenhan \& Seifert

Fusarium sp.

Hypocrea pachybasioides Yoshim. Doi

Isaria fumosorosea Wize

Lecanicillium sp.

Neonectria obtusispora (Cooke \& Harkness) Rossman, L. Lombard \& Crous

Tolypocladium inflatum W. Gams

Trichoderma sp.

Volutella rosea Sacc.

Incertae sedis

Oidiodendron truncatum G.L. Barron

Pseudogymnoascus pannorum senso lato (Link) Minnis \& D.L. Lindner

$P$. roseus Raillo

Verticillium sp.

Microascales

Doratomyces stemonitis (Pers.) F.J. Morton \& G. Sm.

Kernia sp.

Onygenales

Identified to order only

Aphanoascus canadensis Currah

Arachniotus sp.

Arachniotus ruber (Tiegh.) J. Schrot.

$\begin{array}{lll}3 \mathrm{M} & 2 \mathrm{M} & 1 \mathrm{D}, 1 \mathrm{M} \\ 0 & 0 & 1 \mathrm{D}\end{array}$

$1 \mathrm{D} \quad 0 \quad 0$

$1 \mathrm{D}, 2 \mathrm{M} \quad 0 \quad 1 \mathrm{M}$

$4 \mathrm{M} \quad 5 \mathrm{M} \quad 9 \mathrm{M}$

$\begin{array}{lll}0 & 2 \mathrm{M} & 3 \mathrm{M}\end{array}$

$1 \mathrm{M} \quad 0 \quad 0$

$0 \quad 1 \mathrm{M} \quad 0$

$1 \mathrm{M} \quad 0 \quad 0$

$4 \mathrm{M}$

$1 \mathrm{M}$

$1 \mathrm{M}$

0

$2 \mathrm{M}$

0

$\begin{array}{lll}2 \mathrm{D} & 0 & 0 \\ 1 \mathrm{D}, 1 \mathrm{M} & 0 & 0 \\ 1 \mathrm{M} & 0 & 0 \\ 0 & 1 \mathrm{D} & 0 \\ 0 & 1 \mathrm{D} & 0\end{array}$

$0 \quad 0$

0

$1 \mathrm{D}$

$1 \mathrm{D}$

$2 \mathrm{D}$

0

0

$1 \mathrm{M}$

$1 \mathrm{D}, 2 \mathrm{M}$

0

$1 \mathrm{M}$

$1 \mathrm{M}$

0

0

$1 \mathrm{D}$

0

0

2 D

0

$1 \mathrm{M}$

$2 \mathrm{D}$

$1 \mathrm{M}$

$1 \mathrm{D}$

0

0

0

0

$1 \mathrm{D}$

0

0

0

0

$5 \mathrm{M}$

0

$\begin{array}{lll}0 & 0 & 1 \mathrm{D}, 1 \mathrm{M} \\ 0 & 4 \mathrm{M} & 8 \mathrm{M} \\ 3 \mathrm{M} & 1 \mathrm{D}, 3 \mathrm{M} & 2 \mathrm{D}, 2 \mathrm{M} \\ 2 \mathrm{M} & 2 \mathrm{M} & 0\end{array}$

$1 \mathrm{M}$

$1 \mathrm{M}$

$1 \mathrm{D}, 3 \mathrm{M}$

0

0

$1 \mathrm{D}$

\begin{tabular}{lll}
0 & $1 \mathrm{D}$ & 0 \\
0 & $1 \mathrm{D}$ & 0 \\
0 & $1 \mathrm{D}$ & 0 \\
0 & 0 & $1 \mathrm{M}$ \\
\hline
\end{tabular}


Table 2. Continued.

\begin{tabular}{|c|c|c|c|}
\hline \multirow[b]{2}{*}{ Fungi } & \multicolumn{3}{|c|}{ Cave } \\
\hline & $\begin{array}{c}\text { Grotte } \\
\text { de la Baie } \\
\text { de la Tour }\end{array}$ & $\begin{array}{c}\text { Grotte du lac } \\
\text { Maloin }\end{array}$ & $\begin{array}{l}\text { Grotte à la } \\
\text { Patate }\end{array}$ \\
\hline Gymnoascus reesii (Tiegh.) J. Schröt & 0 & 0 & $1 \mathrm{D}$ \\
\hline Trichophyton sp. & 0 & $1 \mathrm{M}$ & 0 \\
\hline \multicolumn{4}{|l|}{ Phyllachorales } \\
\hline Plectosphaerella cucumerina (Lindf.) W. Gams & 0 & $1 \mathrm{D}$ & 0 \\
\hline \multicolumn{4}{|l|}{ Pleosporales } \\
\hline Didymella sp. & $1 \mathrm{D}$ & 0 & 0 \\
\hline Microsphaeropsis sp. & $1 \mathrm{M}$ & 0 & 0 \\
\hline Phoma sp. & $3 \mathrm{D}, 1 \mathrm{M}$ & 0 & 0 \\
\hline P. novae-verbascicola Aveskamp, Gruyter \& Verkley & $1 \mathrm{D}$ & 0 & $1 \mathrm{D}$ \\
\hline P. radicina (McAlpine) Boerema & $1 \mathrm{D}$ & $1 \mathrm{D}$ & 0 \\
\hline \multicolumn{4}{|l|}{ Sordariales } \\
\hline Chaetomium sp. & 0 & 0 & $1 \mathrm{D}$ \\
\hline C. globosum Kunze ex Fr. & 0 & 0 & $1 \mathrm{D}$ \\
\hline Mammaria sp. & 0 & 0 & $1 \mathrm{M}$ \\
\hline \multicolumn{4}{|l|}{ Xylariales } \\
\hline Truncatella angustata (Pers.) S. Hughes & 0 & $2 \mathrm{D}$ & 0 \\
\hline \multicolumn{4}{|l|}{ Basidiomycota } \\
\hline Unidentified & 0 & $1 \mathrm{M}$ & $1 \mathrm{M}$ \\
\hline \multicolumn{4}{|l|}{ Tremellales } \\
\hline Trichosporon dulcitum (Berkhout) Weijman & 0 & 0 & $1 \mathrm{D}, 6 \mathrm{M}$ \\
\hline \multicolumn{4}{|l|}{ Zygomycota } \\
\hline \multicolumn{4}{|l|}{ Mortierellales } \\
\hline Mortierella sp. & $1 \mathrm{M}$ & 0 & 0 \\
\hline \multicolumn{4}{|l|}{ Mucorales } \\
\hline Mucor sp. & $3 \mathrm{M}$ & 0 & $4 \mathrm{M}$ \\
\hline Umbelopsis angularis W. Gams \& M. Sugiyama & 0 & $1 \mathrm{D}$ & 0 \\
\hline \multirow{2}{*}{$\begin{array}{l}\text { U. isabellina (Oudem.) W. Gams } \\
\text { sterile }\end{array}$} & 0 & $1 \mathrm{M}$ & 0 \\
\hline & $4 \mathrm{M}$ & $2 \mathrm{M}$ & $3 \mathrm{M}$ \\
\hline
\end{tabular}

Notes: Number of swabs; Grotte de la Baie de la Tour =6; Grotte du lac Maloin = 5; Grotte à la Patate $=11$.

Total fungal taxa; Grotte de la Baie de la Tour =26; Grotte du lac Maloin =26; Grotte à la Patate $=24$.

Mean number of fungal taxa per swab $\pm \mathrm{SD}$; Grotte de la Baie de la Tour $=9 \pm 4.8$; Grotte du lac Maloin $=9 \pm 5.3$; Grotte à la Patate $=6.0 \pm 2.2$.

Range in number of fungal taxa per swab; Grotte de la Baie de la Tour =2 - 14; Grotte du lac Maloin =2 - 17; Grotte à la Patate $=2-9$.

\section{DiSCUSSION}

We isolated the lowest diversity of fungi in Grotte à la Patate, although sample size was largest for this cave compared to the other two caves sampled. Sampling was conducted deeper within the cave at Grotte à la Patate than at the other two sites, and this may explain the comparatively low fungal diversity. Other studies have found that fungal diversity decreases with increasing distance from cave entrances (Kuzmina et al., 2012; Mulec et al., 2012). Most of the fungal taxa documented during this study have previously been found in caves in other regions (Vanderwolf et al., 2013a). Several fungal genera isolated during this study, such as Cladosporium, Penicillium, and Mucor, are ubiquitous in non-cave environments (Domsch et al., 2007). Sugita et al. (2005) found that Trichosporon spp. were commonly isolated from bat guano in caves in Japan, and we cultured Trichosporon dulcitum exclusively from Grotte à la Patate, the only cave on the island where bat guano was observed. Entomopathogenic genera, such as Isaria, Beauveria, and Tolypocladium (Domsch et al., 2007), were exclusively isolated from Grotte du lac Maloin, where arthropods were more abundant than the other two caves. Fungal genera commonly associated with plants or plant litter, such as Umbelopsis, Catenulifera, Phoma, Cadophora, Fusarium, Truncatella, Phialophora, Verticillium, Didymella, Neonectria, Plectosphaerella cucumerina, Volutella, and Chalara (Meyer and Gams, 2003; Domsch et al., 2007; Bogale et al., 
2010; Arzanlou et al., 2012), were more common in Grotte du lac Maloin and Grotte de la Baie de la Tour. We suggest this is because Grotte du lac Maloin and Grotte de la Baie de la Tour are shorter than Grotte à la Patate and more prone to outside influences. Additionally, stream foam is known to concentrate fungal conidia (Bärlocher and Marvanová 2010) and was present high on the walls in Grotte de la Baie de la Tour. Conifers are the dominant forest cover on Anticosti Island, and several of the fungal genera isolated are frequently associated with conifer litter, such as Scleroconidioma, Thysanophora, Cistella, Cosmospora, and Neonectria (Iwamoto et al., 2005; Koukol, 2009; Grafenhan et al., 2011; Koukol et al., 2012). Some of the isolated fungi are coprophilous, such as Aphanoascus canadensis, Gymnoascus reesii, and Doratomyces stemonitis (Currah, 1985; Domsch et al., 2007).

Previous reports of bats in Grotte à la Patate, our own observations of bat guano in this cave, and microclimate data for Grotte à la Patate relative to elsewhere in the region (Vanderwolf et al., 2012) together suggest this cave is, or was, an active bat hibernaculum and capable of supporting a fungal assemblage that includes Pseudogymnoascus destructans. Since we have previously cultured $P$. destructans from walls in caves on the mainland, even where bats have apparently been extirpated (Vanderwolf et al., 2016b), we conclude that $P$. destructans was not present in the three island caves as of summer 2014. P. destructans is thought to be primarily transmitted by bats and has rapidly spread throughout northeastern North America from its epicenter in New York (Turner et al., 2011). Although McLeod et al. (2015) suggested that bat hibernacula on islands in the Gulf of St. Lawrence, Canada, might have the potential to provide an eastern North American refuge from $P$. destructans, they found that marine straits were only a partial barrier to bat movement. As of the 2015-2016 hibernation period, $P$. destructans had not been documented on Newfoundland, but it has been present since 2013 on Prince Edward Island and Cape Breton Island, other large Gulf of St. Lawrence islands (Heffernan, 2016). Oceanic straits may present a partial barrier for the movement of mainland bats to Anticosti Island, and this may slow the transmission of $P$. destructans and provide a temporary refuge for bats hibernating on the island. Although we did not detect $P$. destructans in caves on Anticosti Island, the closely related $P$. pannorum and $P$. roseus were relatively common. Pseudogymnoascus pannorum is common in caves worldwide (Vanderwolf et al., 2013a), and $P$. roseus is generally associated with soil and wood, particularly in conifer forests (Currah, 1985; Sigler et al., 2000).

Of those fungal genera isolated from cave walls on Anticosti Island, eighteen are identical to those cultured from cave walls in New Brunswick bat hibernacula (unpublished data). Most of the fungal taxa isolated from Anticosti cave walls that we have not isolated previously from cave walls in New Brunswick have been cultured from bats in New Brunswick caves (Vanderwolf et al., 2013b, 2016a). While we found Thysanophora sp. more abundant on cave walls on Anticosti Island relative to those in New Brunswick, several fungal taxa abundant on walls and bats in New Brunswick caves were absent from caves on Anticosti Island. These include taxa such as Leuconeurospora polypaeciloides, $L$. capsici, Phaeotrichum hystricinum, Humicola cf. UAMH 11595, Microascus spp., Preussia sp., Trichosporiella sp., and Arthroderma silverae. In New Brunswick L. polypaeciloides, L. capsici, P. hystricinum, Humicola cf., and Microascus spp are more abundant in caves in which mammal dung is present (Vanderwolf et al., 2013b), while Preussia sp., A. silverae, and $P$. hystricinum are associated with mammal dung in surface environments (Cain, 1956; Domsch et al., 2007; Currah et al., 1996). In addition to overwintering bats ( $M$. lucifugus, M. septentrionalis, Perimyotis subflavus), caves in the Maritimes are frequented, rarely to habitually, by a variety of mammals, including Peromyscus maniculatus, Rattus norvegicus (Norway rat), Castor canadensis (beaver), Mustela sp. (weasel spp.), and especially Erethizon dorsatum and Procyon lotor (McAlpine, 1977; McAlpine et al., 2011; Vanderwolf et al., 2012, 2013b). It appears that the lack of these latter two particular mammal species on Anticosti Island, frequent cave associates elsewhere in Maritime Canada (Calder and Bleakney, 1965; McAlpine, 1979; Moseley, 2007), may influence fungal assemblages present in Anticosti solution caves.

\section{ACKNOWLEDGEMENTS}

Thanks to Gaetan (Alex) Laprise and Danièle Morin of the Québec Ministère des Forêts, de la Faune et des Parcs for much helpful information and advice. Howie Huynh kindly provided field assistance. Thomas Braukmann from the Biodiversity Institute of Ontario assisted with molecular data analysis. Research funding was provided by the Canadian Wildlife Federation and the New Brunswick Museum. Molecular work was supported by the International Barcode of Life project funded by the Ontario Ministry of Research and Innovation and by Genome Canada through the Ontario Genomics Institute.

\section{REFERENCES}

Arzanlou, M., Torbati, M., and Jafary, H., 2012, Fruit rot of olive (Olea europaea) caused by Truncatella angustata: Plant Pathology Quarantine, v. 2 , p. $117-123$. doi: $10.5943 / \mathrm{ppq} / 2 / 2 / 4$.

Bärlocher, F., and Marvanová, L., 2010, Aquatic hyphomycetes (Deuteromycotina) of the Atlantic Maritime Ecozone, in McAlpine, D.F., and Smith, I.M., eds., Assessment of Species Diversity in the Atlantic Maritime Ecozone: Ontario, NRC Research Press, National Research Council Canada. p. 71-106.

Bogale, M., Orr, M.J., O'Hara, M.J., and Untereiner, W.A., 2010, Systematics of Catenulifera (anamorphic Hyaloscyphaceae) with an assessment of the phylogenetic position of Phialophora hyalina: Fungal Biology, v. 114, p. 396-409. doi:10.1016/j.funbio.2010.02.006.

Cain, R.F., 1956, Studies of coprophilous Ascomycetes. II. Phaeotrichum, a new cleistocarpous genus in a new family, and its relationships: Canadian Journal of Botany, v. 34, p. 675-688. doi:10.1139/b56-049. 
Calder, D.R., and Bleakney, J.S., 1965, Microarthropod ecology of a porcupine-inhabited cave in Nova Scotia: Ecology, v. 46, no. 6, p. 895899. doi:10.2307/1934031.

Cameron, A.W., 1958, The mammals of Anticosti Island: National Museum of Canada Bulletin, v. 154, p. 54-66.

Currah, R.S., 1985, Taxonomy of the Onygenales - Arthrodermataceae, Gymnoascaceae, Myxotrichaceae, and Onygenaceae: Mycotaxon, v. 24, p. $1-216$.

Currah, R.S., Abbott, S.P., and Sigler, L., 1996, Arthroderma silverae sp. nov and Chrysosporium vallenarense, keratinophilic fungi from arctic and montane habitats: Mycological Research, v. 100, p. 195-198. doi:10.1016/ S0953-7562(96)80121-3.

Darmon, G., Hidding, B., and De Bellefeuille, S., Tremblay, J.-P., and Côté, S.D., 2013, A generalist rodent benefits from logging regardless of deer density: Ecoscience, v. 20, no. 4, p. 319-327. doi:10.2980/20-4-3612.

Dickson, G.W., 1975, A preliminary study of heterotrophic microorganisms as factors in substrate of troglobitic invertebrates: NSS Bulletin, v. 37, p. 89 93.

Domsch, K.H., Gams, W., and Anderson, T.-H., 2007, Compendium of Soil Fungi, second edition: Eching, Baveria, Germany, IHW-Verlag, 672 p.

Environment Canada, 2015, Daily climate data reports of Port-Menier, Quebec's station from 2010 - 2015: Atmospheric Environment Service, Ottawa, Ontario.

Gardes, M., and Bruns, T.D., 1993, ITS primers with enhanced specificity of basidiomycetes: Application to the identification of mycorrhizae and rusts: Molecular Ecology, v. 2, p.113-118. doi:10.1111/j.1365-294X.1993. tb00005.x.

Gräfenhan, T., Schroers, H.-J., Nirenberg, H.I., and Seifert, K.A., 2011, An overview of the taxonomy, phylogeny, and typification of nectriaceous fungi in Cosmospora, Acremonium, Fusarium, Stilbella, and Volutella: Studies in Mycology, v. 68, p. 79-113. doi:10.3114/sim.2011.68.04.

Hajibabaei, M., deWaard, J.R., Ivanova, N.V., Ratnasingham, S., Dooh, R.T., Kirk, S.L., Mackie, P.M., and Hebert, P.D.N., 2005, Critical factors for assembling a high volume of DNA barcodes: Philosophical Transactions of the Royal Society of London B Biological Sciences, v. 360, no. 1462, p.1959-1967. doi:1098/rstb.2005.1727.

Heffernan, L., 2016, White-nose syndrome map 02/16/2016. 1 sheet. https:// www.whitenosesyndrome.org/sites/default/files/wns_map_20160216.jpg.

Ivanova, N.V., Fazekas, A.J., and Hebert, P.D.N., 2008. Semi-automated, membrane-based protocol for DNA isolation from plants: Plant Molecular Biology Reporter, v. 26, p.186-198. doi:10.1007/s11105-008-0029-4.

Iwamoto, S., Tokumasu, S., Suyama, Y., and Kakishima, M., 2005, Thysanophora penicillioides includes multiple genetically diverged groups that coexist respectively in Abies mariesii forests in Japan: Mycologia, v. 97, no. 6, p. 1238-1250. doi:10.3852/mycologia.97.6.1238.

Koukol, O., 2009, Geographical distribution of Scleroconidioma sphagnicola in coniferous forests in Europe and Canada: Czech Mycology, v. 61, no. 1, p. $117-124$.

Koukol, O., Kolařík, M., Kolářová, Z., and Baldrian, P., 2012, Diversity of foliar endophytes in wind-fallen Picea abies trees: Fungal Diversity, v. 54, p. 69-77. doi:10.1007/s13225-011-0112-2.

Kuzmina, L.Yu., Galimzianova, N.F., Abdullin, Sh.R., and Ryabova, A.S., 2012, Microbiota of the Kinderlinskaya Cave (South Urals, Russia): Microbiology, v. 81, no. 2, p. 251-258. doi:10.1134/S0026261712010109.

Lauriol, B., Roberge, J., and St-Pierre, L., 1987, Relationship between geomorphology, climate, and hydrochemistry in the Patate Cave, Anticosti Island, Canada: Zeitschrift Fur Geomorphologie, v. 31, no. 4, p. 419-431.

McAlpine, D.F., 1977, Notes on cave utilization by beaver: NSS Bulletin, v. 39, p. $90-91$.

McAlpine, D.F., 1979, Preliminary investigations on the solution caves of New Brunswick: Journal of the New Brunswick Museum, v. 1979, p. 99 107.

McAlpine, D.F., Vanderwolf, K.J., Forbes, G.J., and Malloch, D., 2011, Consumption of bats (Myotis spp.) by raccoons (Procyon lotor) during an outbreak of white-nose syndrome in New Brunswick, Canada: implications for estimates of bat mortality: Canadian Field-Naturalist, v. 125, p. 257-260.

McLeod, B.A., Burns, L.E., Frasier, T.R., and Broders, H.G., 2015, Effect of oceanic straits on gene flow in the recently endangered little brown bat (Myotis lucifugus) in maritime Canada: implications for the spread of white-nose syndrome: Canadian Journal of Zoology, v. 93, p. 427-437. doi:10.1139/cjz-2014-0262.

Meyer, W., and Gams, W., 2003, Delimitation of Umbelopsis (Mucorales, Umbelopsidaceae fam. nov.) based on ITS sequence and RFLP data:
Mycological Research, v. 107, no. 3, p. 339-350. doi:10.1017/ S0953756203007226.

Min, K.H., 1988, Fungus flora of Seongrya Cave in Korea: Transactions of the Mycological Society of Japan, v. 29, p.479-487.

Moseley, M., 2007, Acadian biospeleology: composition and ecology of cave fauna of Nova Scotia and southern New Brunswick, Canada: International Journal of Speleology, v. 36, no 1, p. 1-21.

Mulec, J., Vaupotič, J., and Walochnik, J., 2012, Prokaryotic and eukaryotic airborne micoorganisms as tracers of microclimatic changes in the underground (Postojna Cave, Slovenia): Microbial Ecology, v. 64, p. 654-667. doi:10.1007/s00248-012-0059-1.

Newsom, W.M., 1937, Mammals on Anticosti Island: Journal of Mammalogy, v. 18 , p. $435-442$. doi: $10.2307 / 1374333$.

Papavizas, G.C., and Davey, C.B., 1959, Evaluation of various media and antimicrobial agents for isolation of soil fungi: Soil Science, v. 88, p. 112117.

Plamondon, F., 2009, Inventaire des chauves-souris au parc national d'Anticosti: Société des établissements de plein air du Québec et Parcs Québec, Bulletin de Conservation, 2009, p. 3.

Roberge, J., Lauriol, B., and Saint-Pierre, L., 1985, La morphogénèse de la caverne à la Patate, île d'Anticosti, Québec: Géographie physique et Quaternaire, v. 39, no .1, p. 67-75. doi:10.7202/032585ar.

Seifert, K., Morgan-Jones, G., Gams, W., and Kendrick, B., 2011, The Genera of Hyphomycetes: Utrecht, Netherlands, CBS-KNAW Fungal Biodiversity Centre, CBS Biodiversity Series 8, $997 \mathrm{p}$

Sigler, L., Lumley, T.C., and Currah, R.S., 2000, New species and records of saprophytic ascomycetes (Myxotrichaceae) from decaying logs in the boreal forest: Mycoscience, v. 41, p. 495-502. doi:10.1007/BF02461670.

Sugita, T., Kikuchi, K., Makimura, K., Urata, K., Someya, T., Kamei, K., Niimi, M., and Uehara Y., 2005, Trichosporon species isolated from guano samples obtained from bat-inhabited caves in Japan: Applied and Environmental Microbiology, v. 71, p. 7626-7629. doi:10.1128/AEM. 71.11.7626-7629.2005.

Trevor-Deutsch, B., 1973, The role of hibernating bats in the winter diet of Peromyscus spp. (Rodentia; Cricetidae) [PhD dissertation], Carleton University, Ottawa, $127 \mathrm{p}$.

Turner, G.G., Reeder, D.M., and Coleman, J.T.H., 2011, A five-year assessment of mortality and geographic spread of white-nose syndrome in North American bats and a look to the future: Bat Research News, v. 52, no. 2 , p. $13-27$.

United States Fish and Wildlife Service, 2012, Revised decontamination protocol (June 25, 2012), http://www.whitenosesyndrome.org/resource/ revised-decontamination-protocol-june-25-2012.

Vanderwolf, K.J., McAlpine, D.F., Forbes, G.J., and Malloch, D., 2012, Bat populations and cave microclimate prior to and at the outbreak of whitenose syndrome in New Brunswick: Canadian Field Naturalist, v. 126, p. 125-134.

Vanderwolf, K.J., Malloch, D., McAlpine, D.F., and Forbes, G.J., 2013a, A world review of fungi, yeasts, and slime molds in caves: International Journal of Speleology, v. 42(1), p. 77-96. doi:10.5038/1827-806X.42.1.9.

Vanderwolf, K.J., McAlpine, D.F., Malloch, D., and Forbes, G.J., 2013b, Ectomycota associated with hibernating bats in eastern Canadian caves prior to the emergence of white-nose syndrome: Northeastern Naturalist, v. 20 , no. 1 , p. $115-130$.

Vanderwolf, K.J., Malloch, D., and McAlpine, D.F., 2016a, Fungi on whitenose infected bats (Myotis spp.) in Eastern Canada show no decline in diversity associated with Pseudogymnoascus destructans (Ascomycota: Pseudeurotiaceae): International Journal of Speleology, v. 45, no.1, p. 4350. doi:10.5038/1827-806X.45.1.1946.

Vanderwolf, K.J., Malloch, D., and McAlpine, D.F., 2016b, Detecting viable Pseudogymnoascus destructans (Ascomycota: Pseudeurotiaceae) from bat hibernacula walls: effects of media type: Journal of Cave and Karst Studies, v. 78(3): in press.

White, T.J., Bruns, T., Lee, S., and Taylor, J., 1990, Amplification and direct sequencing of fungal ribosomal RNA genes for phylogenetics, in Innis, M.A., Gelfand, D.H., Sninsky, J.J., and White, T.J., eds., PCR Protocols: A Guide to Methods and Applications: New York, Academic Press, p. 315322. doi:10.1016/B978-0-12-372180-8.50042-1.

Yoder, J.A., Benoit, J.B., Christensen, B.S., Croxall, T.J., and Hobbs III, H.H., 2009, Entomopathogenic fungi carried by the cave orb weaver spider, Meta ovalis (Araneae, Tetragnathidae), with implications for mycoflora transer to cave crickets: Journal of Cave and Karst Studies, v. 71, no. 2, p.116-120. 